\title{
Optimum Dietary Crude Protein Level for Fattening Yearling Arsi-Bale Lambs
}

\author{
Getahun Kebede Yadete \\ Ruminant Livestock Research, Debre Zeit Agricultural Research Center, Debre Zeit, Ethiopia
}

\section{Email address:}

getkeb2000@yahoo.com

\section{To cite this article:}

Getahun Kebede Yadete. Optimum Dietary Crude Protein Level for Fattening Yearling Arsi-Bale Lambs. Animal and Veterinary Sciences. Vol. 3, No. 5, 2015, pp. 144-148. doi: 10.11648/j.avs.20150305.15

\begin{abstract}
This study was aimed to determine the optimum dietary crude protein for fattening yearling Arsi-Bale sheep. Thirty-two intact male lambs (live weight $=17.53 \pm 1.57 \mathrm{~kg})$ were randomly assigned to five iso-caloric $(2.12 \mathrm{Mcal} / \mathrm{kg} \mathrm{DM}$ ) dietary treatments (T), varying in crude protein: 9.4\% CP (T1), 10.2\% CP (T2), 11\% CP (T3), 12\% CP (T4) and 13.1\% CP (T5). Intake and growth trial lasted for 87 days, followed by digestibility trial and carcass analysis. Treatments did not differ $(P>0.05)$ in DM intake, ranging from 918.29 (T1) to $928.09 \mathrm{~g} \mathrm{DM} /$ day $(\mathrm{T} 3)$. Crude protein intake increased $(P<0.001)$ with increase in dietary CP $(\mathrm{T} 1,86.71 \mathrm{~g} /$ day; $120 \mathrm{~g}$ /day - T5). Intake of fiber fractions was highest $(P<0.001)$ with $12 \% \mathrm{CP}$ diet. Treatments varied in apparent digestibility of DM $(P<0.05), \mathrm{CP}(P<0.05)$, NDF $(P<0.001)$ and ADF $(P<0.001)$. Average final live weight, total gain and daily gain of lambs were increased non-significantly $(P>0.05)$ from 22.71 to $23.96 \mathrm{~kg} ; 5.37$ to $6.35 \mathrm{~kg} ; 61.78-73.00 \mathrm{~g} /$ day, respectively. Feed conversion ratios were higher $(P<0.001)$ in lambs fed $12 \% \mathrm{CP}$ diet $(12.61)$ and $13 \%$ CP diet (12.76). Urinary nitrogen and total nitrogen excretion were highest for 13\% CP diet (5.02 and $9.19 \mathrm{~g} / \mathrm{day}$; $P<0.001)$. Nitrogen balance was peaked $(12.70 \mathrm{~g} /$ day, $P<0.001)$ with $12 \% \mathrm{CP}$ diet. There was no significant differences $(P>0.05)$ among treatments in slaughter weight, hot carcass weight, DP, fat and bone proportions. However, hot carcass weight increased from 8.8 to $9.8 \mathrm{~kg}$ and DP from 39.4 to 42.15 , with feed CP increase to $12 \%$. The results of this study indicated that optimum dietary CP for improved growth and feed utilization of yearling Arsi-Bale lambs, growing from 17 to $25 \mathrm{~kg}$ is $12 \%$ at the specified dietary energy. Suggested, detail study, applying "comparative slaughter technique" is warranted to support the present findings.
\end{abstract}

Keywords: Yearling Lambs, Weight Gain, Dietary Protein

\section{Introduction}

Sheep production plays a crucial role in Ethiopia, majorly serving as a family food (meat) and income source from sale of live sheep. There exist 29.33 million sheep population in Ethiopia [5] that entirely raised under traditional production system- characterized by low input-output. The productivity of sheep is very low as explained by annual off-take rate of $33 \%$ and average carcass weight of $10 \mathrm{~kg} / \mathrm{head}$ [7]. The productivity is hindered by feed deficit (inadequate amount and quality), low genetic potential of sheep and prevalence of disease and parasites. Sheep are raised entirely on grazing pasture and rarely supplemented with concentrates. Feed deficit is aggravated with dry season and drought occurrence, when dry roughages remain major available feed and protein is the most limiting macronutrient. Most sheep are sold to local markets at around yearling age (live weight below $20 \mathrm{~kg}$ ) often without supplementation (body conditioning) before marketing. However, some farmers traditionally fatten their sheep before marketing, with little concentrate supplementation on top of grazing.However, there is uncertainty that the supplementation could support the nutrient requirement for maximum growth of sheep. Moreover, this system of feeding would sometimes lead to over or under utilization of available feed nutrient that may lead to its wastage and uneconomic feeding.

Feeding sheep based on their nutrient requirement at different production phases is not common practice in Ethiopia. On the other hand, most of the developed feeding standards initially based temperate wool breed sheep [17] and some tropical sheep breeds [12, 19] have been used in improved sheep production systems. According to Andrew and Orskov [3], the maximum live weight gain and nitrogen retention of temperate breed lambs on high plane of nutrition, growing from 15 to $40 \mathrm{~kg}$ were achieved at $17 \%$ dietary CP. In addition, National Research Council (NRC) [17] 
recommended a diet containing $14.5 \% \mathrm{CP}$ for maximum growth of early weaned lambs. Unlike that for temperate breeds, Kearl [12] and Paul et al [19] recommended a lower levels of dietary CP and energy for growing tropical sheep at different growth rates and live weights.

Although nutrient requirement tables developed for tropical sheep are believed to meet the requirements of indigenous sheep breeds of Ethiopia, it has been rarely accepted and applied, as the recommendations based estimates obtained from a specific breed, which may not necessarily represent local sheep. Also, differences in the quality of feed and utilization efficiency by animal may contribute to this uncertainty. The differences in nutrient requirement of animals lie on breed, age, physiological status, growth potential, feed quality and environmental factors, such as temperature, air humidity, solar radiation and wind speed [17]. However, there is no/little information on nutrient requirements specific to indigenous sheep breeds of Ethiopia. Therefore, this study was aimed to determine the optimum dietary crude protein for maximum growth and feed utilization of yearling Arsi-Bale lambs in feedlot.

\section{Materials and Methods}

\subsection{Study Area}

The experiment was conducted at sheep research station of Debre Zeit Agricultural Research Centre, located at 45 $\mathrm{km}$ South East of Addis Ababa $\left(08^{\circ} 44^{\prime} \mathrm{N} 38^{\circ}, 58^{\prime} \mathrm{E}\right.$; average altitude of $1900 \mathrm{~m}$ a.s.1), Ethiopia. The area is known for bimodal rainfall pattern with average annual rainfall of 845 $\mathrm{mm}$ and annual minimum and maximum temperature of 10 and $22{ }^{\circ} \mathrm{C}$, respectively. The area is characterized by mixedcrop-livestock production system, with major crops grown include tef (Eragrostis tef), wheat, chick pea and lentil.

\subsection{Treatments and Feed Composition}

Table 1. Feed ingredients and chemical composition (\%DM).

\begin{tabular}{llllll}
\hline & T1 & T2 & T3 & T4 & T5 \\
\hline \% Diet composition & & & & & \\
Straw & Straw & Straw & Straw & Straw & Straw \\
*Noug cake & - & 6.0 & 19.9 & 35.0 & 47.2 \\
*Wheat bran & 82.3 & 80.8 & 62.9 & 49.9 & 6.0 \\
*Maize grain & 15.6 & 3.0 & 7.0 & 12.9 & 16.1 \\
*Wheat middling & - & 8.1 & 8.1 & - & 28.6 \\
*Limestone & 1.1 & 1.1 & 1.1 & 1.1 & 1.1 \\
salt & 1.0 & 1.0 & 1.0 & 1.0 & 1.0 \\
Total & 100 & 100 & 100 & 100 & 100 \\
Chemical composition:(\% DM) & & & & & \\
DM & 91.46 & 91.55 & 91.53 & 91.84 & 92.30 \\
CP & 9.43 & 10.26 & 11.06 & 12.06 & 13.10 \\
Ash & 12.25 & 12.69 & 12.91 & 10.67 & 9.71 \\
NDF & 48.66 & 52.86 & 55.79 & 56.77 & 54.80 \\
ADF & 26.71 & 26.43 & 28.15 & 31.65 & 29.18 \\
ADL & 5.65 & 5.75 & 6.33 & 7.61 & 7.20 \\
ME (Mcal kg-1) & 2.14 & 2.13 & 2.12 & 2.11 & 2.11 \\
\hline
\end{tabular}

$\mathrm{ME}=$ Metaboliszable energy; calculated according to Kearl [11]. * \% DM of concentrate mix. Ratio of straw to concentrate offered was $65: 35$, on as fed basis.
The diets were similar in composition, with the exception of noug seed cake and wheat middling (diet1) and wheat middling (diet4) exclusion for the purpose of balancing (Table 1). Maize grain, wheat bran, noug seed cake, wheat middling, salt and limestone constituted concentrate part that contained 14, 16, 18, 20 and $22 \% \mathrm{CP}$ in the respective treatments, leading to differences in dietary $\mathrm{CP}(9.43 \% \mathrm{CP}$ in $\mathrm{T} 1,10.26 \% \mathrm{CP}$ in $\mathrm{T} 2,11.06 \% \mathrm{CP}$ in $\mathrm{T} 3 ; 12.06 \% \mathrm{CP}$ in $\mathrm{T} 4$ and $13.1 \% \mathrm{CP}$ in $\mathrm{T} 5)$. The diets were formulated to be nearly iso-caloric (2.12 Mcal $\mathrm{ME} / \mathrm{Kg} \mathrm{DM}$ ) and meet the energy requirement for growing tropical sheep [12]. The diet containing $9.4 \% \mathrm{CP}$ was used as negative control, while $13 \% \mathrm{CP}$ diet was positive control. All diets were similar in DM content, but differed in NDF, ADF and ADL.

\subsection{Animals and Feeding Management}

Thirty-two yearling male Arsi-Bale sheep with mean initial live weight of $17.53 \pm 1.57 \mathrm{~kg}$ were purchased from local markets and treated against endo-and ecto-parasites and vaccinated for common viral diseases. All animals were individually penned in a house with concrete floor and adapted to indoor feeding management for two weeks, before commencing the experiment. Then, they were randomly assigned to five dietary treatments in completely randomised design.

Feed was provided twice daily at 8:30 a.m and 2:00 p.m ensuring $15 \%$ refusal for each animal. The amount of straw and concentrate offered were adjusted daily based on previous day intake, where straw to concentrate ratio was 65:35, on as fed basis. Water was provided in a bucket free of choice. Feed offered and refusals were measured daily and feed intake was calculated as the difference between the two measurements. Representative feed samples were taken daily and sub-sampled every 15 days. All animals were weighed biweekly after overnight ( 16 hours) deprivation of feeds and water.

At the end of the feeding period ( 87 days), three lambs were selected per treatment and transferred to metabolic crate with slotted floor, individually. The animals were adapted to the attached fecal bags and urine funnels for three days followed by collection of fecal and urine for seven days. All animals were with unlimited access to water. Urine was directly poured into a glass bottle containing drops of sulfuric acid to prevent ammonia loss. The amount of feces and urine produced per animal/day was measured and recorded. About $10 \%$ of the daily fecal and urine outputs were sampled per animal and stored in a deep freezer $\left(-20^{\circ} \mathrm{C}\right)$ until sub-sampled for laboratory analysis. Moreover, three animals were randomly selected per treatment and slaughtered for carcass analysis. The animals were slaughtered after 24 hour of feed deprivation. Measurements were taken for slaughter weight, hot carcass weight (HCW) and carcass components (bone, fat and lean, trimmings). Dressing percentage (DP) was calculated as: $(\mathrm{HCW} / \mathrm{SW}) * 100$. 


\subsection{Sample Chemical Analysis}

Feed and fecal dry matter (DM), crude protein (CP) and Ash were determined according to the procedures of AOAC [4], while neutral detergent fiber (NDF), acid detergent fiber (ADF) and acid detergent lignin (ADL) were determined according to Van Soest et al [22].

\subsection{Statistical Analysis}

Data was analyzed using the General Linear Model (GLM) procedure of SAS [20]. Treatment means of the parameters were separated using Duncan Multiple Range Test. The statistical model used for feed intake, live weight change, digestibility, feed conversion ratio, carcass parameters and nitrogen utilization was: $Y i j=\mu+\alpha i+\in \mathrm{ij}$, Where, $\mu=$ Grand mean; $\alpha i=$ Effect of treatment feeds; and $\in \mathrm{ij}=$ Experimental error. Data on average daily gain (ADG) for each lamb was computed by regressing the live weight incurred in two weeks interval over the number of days elapsed.

\section{Results and Discussion}

Table 2. Effect of dietary crude protein level on intake and apparent digestibility of nutrients.

\begin{tabular}{|c|c|c|c|c|c|c|c|c|}
\hline & & Treatment & & & & & & \\
\hline Parameter & & T1 $(n=6)$ & T2 $(n=6)$ & T3 $(n=6)$ & T4 $(n=7)$ & T5 $(n=7)$ & SEM & P value \\
\hline \multirow{7}{*}{$\begin{array}{l}\text { Intake } \\
\text { (g/day) }\end{array}$} & DM & $920.26 \mathrm{ba}$ & $918.29 \mathrm{~b}$ & $928.09 \mathrm{ab}$ & $920.33 \mathrm{ab}$ & $922.23 \mathrm{ab}$ & 3.17 & 0.2262 \\
\hline & $\mathrm{CP}$ & $86.71 \mathrm{e}$ & $94.13 \mathrm{~d}$ & $102.61 \mathrm{c}$ & $110.87 \mathrm{~b}$ & $120.63 a$ & 0.37 & $<.001$ \\
\hline & ME & $1.97 \mathrm{a}$ & $1.95 \mathrm{ab}$ & $1.96 \mathrm{ab}$ & $1.94 \mathrm{~b}$ & $1.95 \mathrm{ab}$ & 0.01 & $<.001$ \\
\hline & Ash & $112.71 \mathrm{c}$ & $116.61 \mathrm{~b}$ & $119.81 \mathrm{a}$ & $98.22 \mathrm{~d}$ & $89.51 \mathrm{e}$ & 0.39 & $<.001$ \\
\hline & NDF & $447.81 \mathrm{e}$ & $485.39 \mathrm{~d}$ & $517.68 \mathrm{~b}$ & $522.41 \mathrm{a}$ & $505.52 \mathrm{c}$ & 1.74 & $<.001$ \\
\hline & $\mathrm{ADF}$ & $245.86 \mathrm{~d}$ & $242.83 d$ & $261.25 \mathrm{c}$ & $290.93 a$ & $269.31 \mathrm{~b}$ & 0.94 & $<.001$ \\
\hline & $\mathrm{ADL}$ & $52.05 \mathrm{e}$ & $52.85 \mathrm{~d}$ & $58.72 \mathrm{c}$ & $70.05 a$ & $66.41 \mathrm{~b}$ & 0.22 & $<.001$ \\
\hline \multirow{4}{*}{$\begin{array}{l}\text { Digestibility } \\
(\%)\end{array}$} & DM & $55.59 \mathrm{~b}$ & $61.56 \mathrm{a}$ & $54.66 \mathrm{~b}$ & $64.30 \mathrm{a}$ & $60.92 \mathrm{ab}$ & 2.18 & 0.0393 \\
\hline & $\mathrm{CP}$ & $59.91 \mathrm{ab}$ & $59.55 \mathrm{ab}$ & $58.55 \mathrm{~b}$ & $65.49 \mathrm{ab}$ & $66.54 \mathrm{a}$ & 2.32 & 0.0477 \\
\hline & NDF & $64.88 \mathrm{bc}$ & $74.79 \mathrm{a}$ & $63.0 \mathrm{bc}$ & $67.11 \mathrm{~b}$ & $60.41 \mathrm{c}$ & 2.07 & $<.001$ \\
\hline & $\mathrm{ADF}$ & $62.24 \mathrm{~b}$ & $71.75 \mathrm{a}$ & $49.58 \mathrm{c}$ & $66.60 \mathrm{ab}$ & $53.4 \mathrm{c}$ & 2.65 & $<.001$ \\
\hline
\end{tabular}

a,b,c,d,e Values with different superscripts within same row are significantly different; $\mathrm{DM}=\mathrm{dry}$ matter intake; $\mathrm{CPI}=$ crude protein intake; AshI= ash intake; $\mathrm{NDFI}=$ neutral detergent fiber intake; $\mathrm{ADFI}=$ acid detergent fiber intake; $\mathrm{ADLI}=$ acid detergent intake; $\mathrm{SEM}=$ standard error of mean; $\mathrm{n}=$ number of lambs

\subsection{Live Weight Change and Feed Conversion Ratio (FCR)}

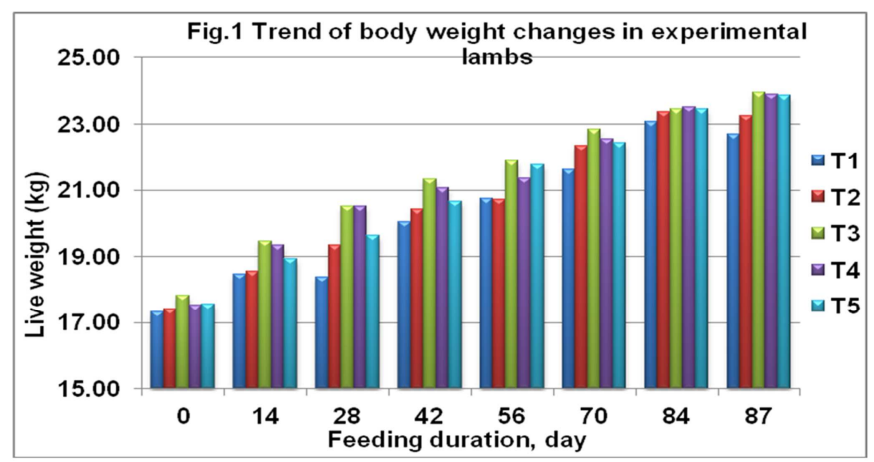

Although non-significant $(P>0.05)$, an improve in the average final live weight $(22.71$ vs. $23.96 \mathrm{~kg})$, total gain $(5.37$ vs $6.35 \mathrm{~kg})$ and average daily gain $(61.78$ vs 73.00 $\mathrm{g} /$ day) were observed with increase in dietary $\mathrm{CP}$. The observed changes in growth performance with higher CP diet probably resulted from increase in feed intake. In agreement

\subsection{Nutrient Intake and Digestibility}

The effect of treatments was not significant on dry matter intake $(P>0.05)$, ranging from 918.3 (T1) to $928.1 \mathrm{~g}$ /day per lamb (T3). The magnitude of DM intake observed in the present study is comparable with previous studies for ArsiBale lambs maintained on roughage and concentrate $[6,8]$, but higher than that reported for Afar and Black head Ogaden lambs [9]. Studies have shown that a non-significant feed intake with sheep fed diets containing $9 \%$ to $13 \%$ CP [2], in Saanen kids fed $14 \%$ to $16 \%$ CP diets [15] and Korean black goats consumed $14-20 \% \mathrm{CP}$ diet [11]. In the present study, intake of crude protein linearly increased $(P<0.001)$ with increase in dietary $\mathrm{CP}$, where lambs on $13 \% \mathrm{CP}$ diet consumed $120 \mathrm{~g} \mathrm{CP} /$ day. Also, intake of fiber fractions increased with increase in dietary $\mathrm{CP}$, the highest value obtained with $12 \% \mathrm{CP}$ diet. Although change in the apparent digestibility of nutrients was non-linear with change in dietary $\mathrm{CP}$, there was variation in digestibility of $\mathrm{DM}$ $(P<0.05), \quad \mathrm{CP} \quad(P<0.05), \quad \mathrm{NDF} \quad(P<0.001)$ and $\mathrm{ADF}$ $(P<0.001)$. The apparent digestibility of nutrients was greater with T2 and T4 diets, and lowest with T3 diet. 
Table 3. Effect of dietary crude protein on live weight change and feed conversion ratio (FCR).

\begin{tabular}{|c|c|c|c|c|c|c|c|}
\hline & $T 1(n=6)$ & T2 $(n=6)$ & T3 $(n=6)$ & T4 $(n=7)$ & T5 $(n=7)$ & SEM & P value \\
\hline Initial wt, kg & 17.33 & 17.41 & 17.83 & 17.53 & 17.57 & 0.68 & 0.9886 \\
\hline Final wt, kg & 22.71 & 23.25 & 23.96 & 23.88 & 23.86 & 0.81 & 0.7814 \\
\hline Total gain, $\mathrm{kg}$ & 5.37 & 5.83 & 6.12 & 6.35 & 6.28 & 0.70 & 0.8673 \\
\hline $\mathrm{ADG}, \mathrm{g}$ & 61.78 & 67.05 & 70.40 & 73.00 & 72.25 & 8.12 & 0.8673 \\
\hline FCR & $14.90 \mathrm{c}$ & $13.70 \mathrm{~b}$ & $13.18 \mathrm{~b}$ & $12.61 \mathrm{a}$ & $12.76 \mathrm{a}$ & 0.24 & $<0.001$ \\
\hline
\end{tabular}

a,b,c Values with different superscripts within same rows are significantly different; $F C R=$ feed conversion ratio(g DMI/g gain); ADG=average daily gain; $\mathrm{SEM}=$ standard error of mean; $\mathrm{n}=$ number of animals.

\subsection{Nitrogen Utilization}

Table 4. Nitrogen utilization (g/day) in lambs fed the experimental diets.

\begin{tabular}{llllll}
\hline Treatments & NI & UN & FN & TN & NB \\
\hline 1 & $15.03 \mathrm{e}$ & $1.52 \mathrm{c}$ & 3.76 & $5.29 \mathrm{~d}$ & $9.74 \mathrm{~d}$ \\
2 & $16.21 \mathrm{~d}$ & $4.12 \mathrm{ab}$ & 4.20 & $8.32 \mathrm{c}$ & $7.89 \mathrm{e}$ \\
3 & $17.72 \mathrm{c}$ & $2.43 \mathrm{c}$ & 4.68 & $7.11 \mathrm{c}$ & $10.61 \mathrm{~cd}$ \\
4 & $19.57 \mathrm{~b}$ & $3.06 \mathrm{bc}$ & 3.81 & $6.87 \mathrm{dc}$ & $12.70 \mathrm{ab}$ \\
5 & $21.08 \mathrm{a}$ & $5.02 \mathrm{a}$ & 4.18 & $9.19 \mathrm{a}$ & $11.89 \mathrm{cb}$ \\
SEM & 0.103 & 0.431 & 0.417 & 0.623 & 0.646 \\
P- value & $<0.001$ & $<0.001$ & 0.5358 & 0.0005 & $<0.001$ \\
\hline
\end{tabular}

a,b,c,d,e values with different superscripts within same column are significantly different; $\mathrm{UN}=$ urine nitrogen, g/d; $\mathrm{FN}=$ fecal $\mathrm{N} ; \mathrm{NI}=\mathrm{N}$ intake;

$\mathrm{TN}=$ total $\mathrm{N}$ excreted; $\mathrm{NB}=$ nitrogen balance; $\mathrm{SEM}=$ standard error of mean

Nitrogen intake (NI), urinary nitrogen(UN) and total nitrogen excretion $(\mathrm{TN})$ increased $(P<0.001)$ with increase in dietary CP (Table 4). The highest NI(21.08), UN(5.02), and TN excretion (9.19 g/day) were observed in $13 \% \mathrm{CP}$ diet. Treatments did not vary $(P>0.05)$ in the level of fecal nitrogen excretion. An increase $(P<0.001)$ in nitrogen balance $(\mathrm{NB})$ was seen with increased dietary $\mathrm{CP}$, being the highest $(12.70 \mathrm{~g} /$ day $)$ in $12 \% \mathrm{CP}$ diet. Osuagwuh and Akinsoyinu [18] reported an increase in NI, UN, FN and N retention for West African dwarf goats, as the level of crude protein in the supplement increased from 5\% to $25 \% \mathrm{DM}$. However, there was no significant difference $(P>0.05)$ in nitrogen balance between lambs fed $12 \%$ and $13 \% \mathrm{CP}$ diets. The result shows that the higher nitrogen balance, the better the growth performances of lambs.

\subsection{Carcass Analysis}

There was no real difference $(P>0.05)$ among treatments in SW, HCW, DP, fat and bone yields (Table 5). However, the magnitude of HCW increased by about $10 \%$ (8.88 vs. $9.8 \mathrm{~kg})$ and that of DP increased by $6.5 \%(39.38$ vs. $42.15 \mathrm{~kg})$, as feed CP increased from $9.4 \%$ to $12 \%$. Studies have shown that DP increases as SW increases [14, 16]. However, the fact that no remarkable change in DP in the present study might have resulted from the lower SW of sample animals. In this study, lean meat yield increased $(P<0.05)$ with increase in feed $\mathrm{CP} \%$, where the highest value $(6.52 \mathrm{~kg})$ was observed with $13 \%$ CP diet. Similarly, lean to bone and lean to fat ratios were highest for $13 \% \mathrm{CP}$ diet compared to $9.4 \% \mathrm{CP}$ diet. There was no significant change in the proportion of fat, bone and meat for Korean Black goat kept on $14 \%$ to $20 \%$ CP diet [11].

Table 5. Effect of dietary crude protein level on carcass parameters of experimental lambs.

\begin{tabular}{|c|c|c|c|c|c|c|c|}
\hline Parameter & T1 $(n=3)$ & T2 $(n=3)$ & T3 $(n=3)$ & T4 $(n=3)$ & T5 $(n=3)$ & SEM & P-value \\
\hline SW (kg) & 22.50 & 23.75 & 23.83 & 23.33 & 23.83 & 1.46 & 0.9580 \\
\hline HCW(kg) & 8.87 & 9.07 & 9.73 & 9.80 & 9.83 & 0.63 & 0.7177 \\
\hline DP $(\%)$ & 39.39 & 38.21 & 40.77 & 42.15 & 41.34 & 1.60 & 0.4684 \\
\hline Lean(kg) & $4.95 b$ & $5.18 b$ & $5.58 \mathrm{ab}$ & $5.96 \mathrm{ab}$ & $6.52 \mathrm{a}$ & 0.45 & 0.0148 \\
\hline Fat(kg) & 1.26 & 0.90 & 1.35 & 1.14 & 1.01 & 0.19 & 0.4987 \\
\hline Bone(kg) & 2.26 & 2.65 & 2.43 & 2.24 & 2.10 & 0.18 & 0.2980 \\
\hline Trimming, $g$ & $393.3 \mathrm{a}$ & $339.1 \mathrm{ab}$ & $365.0 \mathrm{ab}$ & $460.3 a$ & $201.5 b$ & 56.18 & 0.0794 \\
\hline LFR & $3.96 \mathrm{~b}$ & $6.05 \mathrm{ab}$ & $4.41 \mathrm{ab}$ & $5.47 \mathrm{ab}$ & $6.89 \mathrm{a}$ & 0.87 & 0.1868 \\
\hline
\end{tabular}

a,b,c,d,e Values with different superscripts within same row are significantly different; SW = slaughter weight; HCW= hot carcass weight; DP= dressing percent $\left(\mathrm{HCW} / \mathrm{SW}^{*} 100\right)$; $\mathrm{LBR}=$ lean to bone ratio; $\mathrm{LFR}=$ lean to fat ratio; $\mathrm{SEM}=$ standard error of mean; $\mathrm{n}=\mathrm{no}$. of slaughtered animals

\section{Conclusion}

Based on the results of this experiment, the optimum dietary CP for improved performance and feed utilization of yearling Arsi-Bale lambs, growing from 17 to $25 \mathrm{~kg}$, is about $12 \%$, which synchronizes with $2.11 \mathrm{Mj} / \mathrm{kg} \mathrm{DM}$ feed energy. However, detail studies using "comparative slaughter techniques", is suggested to support the present findings. Moreover, applying the same work for other indigenous sheep breeds is equally important.

\section{Acknowledgement}

The author acknowledged Ethiopian Institute of Agricultural Research for funding this research and availing research inputs. The efforts of technical assistance- $\mathrm{Mr}$ Solomon Abiy and animal attendants: Mrs Workiye Shibru; Mrs Asrat Endale and Mrs Topiya Muhiye is well appreciated. Also, a useful help given by veterinary 
technician - Mrs Kasech Melese is acknowledged.

\section{References}

[1] Abebe Tafa \& Solomon Melaku \& Kurt J. Peters. 201Supplementation with linseed (Linum usitatissimum) cake and/or wheat bran on feed utilization and carcass characteristics of Arsi - Bale sheep. Trop Anim Health Prod (2010) 42:677-68.

[2] Ahn BH, Moon YH (1985). Effect of dietary protein and calcium levels on nutrition in sheep I. Effect of dietary protein and calcium levels on digestibility, nitrogen balance and some mineral retention in sheep. Kor. J. Anim. Sci. 27:507-51.

[3] Andrews, R. P., Orskov, E. R., 1970. The nutrition of early weaned lamb. I. The influence of protein concentration and feeding level on rate of gain in body weight. J. Agric. Sci. (Camb.) 75, 11-1.

[4] AOAC (Association of Official Analytical Chemists), 1990. Official method of analysis. $15^{\text {th }}$ ed. AOAC Inc., Arlington, Virginia, USA. pp. 12-9.

[5] CSA (Central Statistic Authority) of Ethiopia, 201Agricultural sample survey 2014.Vol.II. Report on livestock and livestock characteristics (Private peasant holdings). 194p.

[6] Ermias Tekletsadik. 2008. The Effect of Supplementation with barely bran, linseed meal and their mixtures on the performance of Arsi-Bale sheep fed a basal diet of faba bean haulms. MSc Thesis. Haramaya University, Ethiopia.

[7] FAO (Food and Agricultural Organization of the United Nations), 2004. 2 FAOSTAT data. http://www.faostat.fao.org/faostat/collections?subset=agricult ure.

[8] Getahun Kebede and Kassahun Melese, 2010. Evaluation of poultry litter as substitute of urea in urea molasses block on growth and carcass characteristics of finished lamb. Ethiopian Journal of Animal Production (EJAP). Vol.10;No.,201Pp: 193.

[9] Getahun Kebede Yadete. Effect of Concentrate Supplementation on Performances of Ethiopian Lowland Afar and Blackhead Ogaden Lambs. Animal and Veterinary Sciences. Vol. 2, No. 2, 2014, pp. 36-41. doi: 10.11648/j.avs.20140202.14.

[10] Haddad, S. G., R. E. Nasr \& M. M. Muwalla, 2001.Optimum dietary crude protein level for finishing Awassi lambs. Small Ruminant Research, 39, 41-4.

[11] Hwangbo Soon, Sun Ho Choi, Sang Woo Kim, Dong Soo
Son, Ho Sung Park1Sung Hoon Lee2 and Ik Hwan Jo. 2009. Effects of Crude Protein Levels in Total Mixed Rations on Growth. Performance and Meat Quality in Growing Korean Black Goats. Asian-Aust. J. Anim. Sci. Vol. 22, No. 8: 1133 113.

[12] Kearl, L. C., 1982. Nutrient Requirements of Ruminants in Developing countries. International Feedstuffs Institute, Utah State University, Logan, Utah 84322, USA.

[13] Keser, O., T. Bilal and H. Cankutay, 2008. The effect of different dietary crude protein level on performance and serum immunoglobulin $\mathrm{g}$ in male Kivircik lambs. Bulgarian Journal of Veterinary Medicine (2008), 11, No 1, 49-5.

[14] Marinova, P., Y. Banskalieva, S. Alexandrov, V. Tzvetkova and H. Stanchev. 2001. Carcass composition and meat quality of kids fed sunflower oil supplemented diet. Small Ruminant. Res. 42:217-22.

[15] Mohammad Sharifi, Moslem Bashtani, Abbas Ali Naserian, Hamid Khorasani, 2013. Effect of dietary crude protein level on the performance and apparent digestibility of Iranian Saanen kids. African Journal of Biotechnology Vol. 12(26), pp. $4202-420$.

[16] Mourad, M., G. Gbanamou and L. B. Balde. 2001. Carcass characteristics of West African dwarf goats under extensive system. Small Ruminant. Res. 42:81-8.

[17] NRC (National Research Council), 1985. Nutrient Requirements of Sheep. Sixth Revised Edition. Washington, D.C; National Academic Press.

[18] Osuagwuh, A. I. A., and A. O. Akinsoyinu, 1990. Efficiency of nitrogen utilization by pregnant West African dwarf goats fed various leveles of crude protein in the diet. Small Ruminant Research, volume 3, Issue 4, July 199Pages 363-37.

[19] Paul, S. S., A.B. Mandal, G. P. Mandal, A. Kannan and N. N. Pathak., 2003. Deriving nutrient requirements of growing Indian sheep under tropical conditions usin performance and intake data emanated from feeding trials conducted in different research institutes. Small Rumin. Res. 50: 97-10.

[20] SAS (Statistical Analysis System).2003. SAS Institute. Inc., Cary, NC, USA.

[21] Titi, H. H., M. J. Tabbaa, M. G. Amasheh, F. Barakeh \& B. Daqamseh, 2000. Comparative performance of Awassi lambs and black goat kids on different crude protein levels in Jordan. Small Ruminant Research, 37, 131-13.

[22] Van Soest. P. J., Robertson, J. B., Lewis, B. A, 1991. Methods for dietary fiber, neutral detergent fiber and non-starch polysaccharides in relation to animal nutrition. J. Dairy Sci. 74, 3583-359. 